\title{
Bacterial Degradation of Bacteriostatic Polyphenols, Tannins
}

\author{
Gloria Susan Cherian11,*, Madhan Raja² \\ ${ }^{1}$ Department of Advanced Zoology, Loyola College, Chennai - 600 034, Tamil Nadu, India. \\ ${ }^{2}$ BioLim Centre for Science and Technology, Chennai - 600 023, Tamil Nadu, India.
}

\section{ART I CLE DETAILS}

\section{Article history:}

Received 03 September 2021

Accepted 28 September 2021

Available online 31 October 2021

\section{Keywords:}

Tannin

Bacteria Degradation

Tannase Activity

\begin{abstract}
A B S T R A C T
Tannin degradation by bacteria has not been studied much as tannins are commonly known to be bacteriostatic due to enzyme inhibition, substrate deprivation, and the enzyme activity on the bacterial cell wall. However, about a handful of bacteria have been found to tolerate certain concentrations of tannin. This study focuses on isolating and identifying bacteria from decaying portions of tree bark for tannase production and effective catalysis of ester bond hydrolysis in tannins. Different concentrations of commercial tannic acid were used as the sole carbon source on mineral salt medium (MSM) agar plates, to test the maximum tolerable concentrations (MTCs) by the isolates. Tannin degradation was confirmed by a visual reading method and bacterial tannase activity and the biodegradation percentage were determined. One particular isolate was identified to have $50 \mathrm{~g} / \mathrm{L} \mathrm{MTC}$ of tannin, with a tannase activity of $51.61 \mathrm{U} / \mathrm{mL}$ that is optimum after 96 hours of incubation. The $16 \mathrm{~s}$ rRNA sequencing results showed that the isolate belonged to Bacillus genus and the resulting bacterial strain isolate was found to be a new strain of Bacillus subtilis which was submitted to GenBank under the accession number MH330408.
\end{abstract}

\section{Introduction}

Tannins are complex recalcitrant compounds that are consumed by humans on a regular basis as they are universally present in plants and represent the fourth most abundant group of secondary metabolites after cellulose, hemicellulose and lignins [1]. These are naturally occurring water soluble polyphenols that are found in many parts of plants such as leaves [2], fruits [3], food grains [4], bark and wood etc., [5]. Moreover, they are unique among their contemporaries as they precipitate proteins, minerals, starch, cellulose etc. from solutions [6]. Tannins in other words are water-soluble polyphenols with a molecular mass ranging from $0.3-5$ $\mathrm{kD}$ that are known to be inhibitory against several organisms [7] and are recalcitrant to biodegradation [8]. Their role primarily, has been studied to guard the vulnerable parts of plants from microbial attack by inactivating the invasive microbial extracellular enzymes [9].

As per the studies conducted, continuous exposure to tannins can cause potential health hazards such as damage to the eye, skin, respiratory, and gastrointestinal tract [10]. The usual complexation of proteins to form water insoluble complexes with tannic acid and naturally occurring tannins inactivates the enzymes [11]. Therefore, foods rich in tannins are of low nutritional value as they form irreversible complexes with proteins, starch and digestive enzymes [12].

A certain group of tannins called hydrolysable tannins (e.g. tannic acid) are toxic to animals and cause poisoning if consumed by them in large amounts [13]. While on the other hand, another group called condensed tannins, also known as proanthocyanidins have many health promoting potentials, such as anticancer, antioxidant, anti-inflammatory, antiasthmatic, and antimicrobial properties [14]. However, the large amount of tannins in foods is responsible for its unpleasant taste and an astringent feel [15] and its prolonged exposure may even bring about liver damage and other health complications.

Bearing in mind the adverse health effects caused by these polyphenols, it is necessary to degrade these harmful compounds for their successive elimination from the body. Some methods have been explored to remove tannins, including physical, chemical, biological and other methods. For degradation by microbes, tannase, the hydrolase group of enzymes is solely responsible for tannin degradation and in suppressing its anti- nutritional activities. In other words, it is a universal enzyme that catalyzes the first step of tannin degradation [2].

Tannase is used extensively in pharmaceuticals, food processing, brewing, textiles, detergents and tea industry [16]. However, its applications are limited due to the enzyme being secreted in extremely low amounts causing inadequate substrate binding spectrum and increased cost of purification. Apart from degrading tannic acid, bacterial tannases have also been studied to degrade natural tannins like chestnut and oak tannins, as stated by Lewis and Starkey [17]. Similarly, fungal tannases are very diverse and efficiently degrade different types of hydrolysable tannins [18]. And even though a number of tannins degrading microorganisms have been reported as according to Bhat et al. [3], prolific degraders of tannins and better sources of tannase are still on the lookout.

Recent findings indicate that most of the organisms capable of degrading tannins isolated till date are either anaerobic or facultatively anaerobic bacteria from the alimentary canal of ruminating animals or fungal strains associated with the degradation of wood and forest litter [1]. A major problem studied in the utilization of fungal strains for industrial applications was that degradation by fungi is relatively slow and also that it is difficult to manipulate fungal strains genetically because of their complexity. And although several tannin degrading anaerobic bacteria have been isolated $[19,20]$, the processes based on anaerobic bacteria are slow, and the study of tannin degradation pathway is relatively difficult, which demands for a better and faster tannin degrader.

Although tannase is present in plants, animals, and microorganisms, it is mainly produced by microorganisms $[21,22]$. In view of this, the aim of the present study was to isolate from decaying bark samples some highly sensitive bacteria, preferably new or lesser-known strains with high tannase activity. The bacterial strain degrading tannic acid most effectively was characterized and identified on the basis of 16S rRNA sequencing.

\section{Experimental Methods}

\subsection{Collection and Sample Preparation}

The decaying bark samples were randomly collected in a sterilized petri dish, from a total of seven trees in Ayanavaram, Chennai. The collected bark samples were transferred into a conical flask containing $100 \mathrm{~mL}$ of MSM (mineral salts medium) broth and was homogenized by keeping it in an orbital shaker at $37^{\circ} \mathrm{C}$ for 72 hours. 


\subsubsection{Composition of MSM Supplemented with 3\% Agar}

Tannic acid (2 g/L), $\mathrm{KH}_{2} \mathrm{PO}_{4} \quad(3 \mathrm{~g} / \mathrm{L}) ; \mathrm{Na}_{2} \mathrm{HPO}_{4} .2 \mathrm{H}_{2} \mathrm{O} \quad(6 \mathrm{~g} / \mathrm{L}) ;$ $\mathrm{MgSO}_{4} .7 \mathrm{H}_{2} \mathrm{O}$ (0.1 g/L); yeast extract (8 g/L); $\mathrm{NaCl}(5 \mathrm{~g} / \mathrm{L}) ;$ Agar (3 g/100 $\mathrm{mL})$.

\subsection{Isolation of Tannase Producing Microbes}

MSM Agar was used to cultivate microorganisms and plating was done by serial dilution method [23]. The serially diluted cultures were streaked onto sterile nutrient agar plates containing $2 \%$ tannic acid and the colonies were allowed to develop by incubating the plates at $37{ }^{\circ} \mathrm{C}$ for 24 hours. The isolates obtained were separately streaked and were then maintained on MSM agar slants supplemented with $1 \%$ tannic acid as the sole carbon source. The isolated strains were sub-cultured periodically, and the stock cultures were maintained at $30{ }^{\circ} \mathrm{C}$. The microbial isolates were then tested for their ability to hydrolyze tannin to gallic acid and glucose by the enzyme tannin acyl hydrolase.

\subsection{Identification and Characterization of the Isolated Bacteria}

The isolates obtained was identified and characterized based on morphological and biochemical tests. Gram staining was performed for morphological identification followed by colony characterization. Biochemical tests such as methyl red test, Voges Proskauer test and indole test were performed. Further, the following assays were conducted to check the tannase activity of the isolate.

\subsection{Tannase Activity}

\subsubsection{Maximum Tolerable Concentration}

The maximum tolerable concentration (MTC) of tannins was studied for the highest concentration of tannic acid that allows growth after 24- 48 hrs. The increasing concentration of tannic acid $(1,5,10,20,30,40,50$ $\mathrm{g} / \mathrm{L}$ ) on MSM agar plates were used for testing the MTCs [24].

\subsubsection{Visual Detection Assay}

Isolation of tannase-producing bacteria was carried out as per the method of Osawa and Walsh [25] and our newly developed method. The inoculum suspension was poured into wells made on nutrient agar plates supplemented with tannic acid (0.1\%; filter sterilized). Further, in our newly developed method, a liquid inoculum suspension of MSM broth supplemented with $1 \%$ tannic acid was prepared to allow release of the tannase enzyme by the isolates in separate conical flasks. Crude enzyme containing inoculum that had been incubated for up to 72 hours was then directly poured into wells created on purely agar containing plates, with tannic acid added as the substrate for enzyme activity. Addition of tannic acid to nutrient agar forms a tannin protein complex; cleavage of this complex by bacteria producing tannase forms a dark zone of clearance.

\subsubsection{Tannase Specific Assay}

This is a colorimetric method studied by Brahmbhatt and Modi [26] where tannase breaks tannic acid which acts as a substrate, forming gallic acid and liberating glucose. Tannase activity was determined by estimating the reduced glucose liberated using 3, 5-dinitrosalicylic acid reagent. One unit of tannase activity was defined as the amount of enzyme releasing $1 \mu \mathrm{molmin}^{-1}$ of glucose under assay conditions.

Standard curve was studied by preparing dilutions up to $1000 \mu \mathrm{g} / \mathrm{mL}$ of glucose solution. The activity was determined by using the supernatant or filtered cell-free broth obtained after centrifugation at $8000 \mathrm{rpm}$ at 20 ${ }^{\circ} \mathrm{C}$ for $15 \mathrm{~min}$ and pre-incubating it with $0.1 \mathrm{M}$ acetate buffer (pH 5.0) containing $0.5 \%$ tannic acid as substrate. $1 \mathrm{~mL}$ of crude enzyme was reacted with the equal amount of substrate, dissolved in the buffer and incubated for $30 \mathrm{~min}$ at $37^{\circ} \mathrm{C}$ followed by the incubation in boiling water bath for another $15 \mathrm{~min}$ to deactivate the enzyme-substrate activity. From this $2 \mathrm{~mL}$ system, $1 \mathrm{~mL}$ was withdrawn and reacted with 3,5dinitrosalicylic acid reagent and finally the system was diluted by adding $10 \mathrm{~mL}$ distilled water and absorbance was measured at $540 \mathrm{~nm}$ on spectrophotometer. All the tests were performed in triplicates.

\subsubsection{Biodegradation Percentage Determination Assay}

Tannin concentrations in the supplemented media were also measured by bovine serum albumin (BSA) precipitation assay during time intervals [27]. For biodegradation experiments, in the media supplemented with upto $50 \mathrm{~g} / \mathrm{L}$ of tannic acid, tannin concentration was measured by bovine serum albumin (BSA) precipitation assay after 24, 48, 72, 96, 120 and 144 hours of incubation and the biodegradation percentage was calculated [28]. $5 \mathrm{~mL}$ of the bacterial suspensions or the cell free broth was centrifuged $\left(3,000 \mathrm{rpm}\right.$ at $4^{\circ} \mathrm{C}$ for $\left.10 \mathrm{~min}\right)$ and the supernatant was taken to determine tannins. The pellet obtained was air dried and weighed to check the increasing biomass of the bacterial sample. For each sample, 1 $\mathrm{mL}$ of a $1 \mathrm{mg} \mathrm{BSA} / \mathrm{mL}$ acetate buffer stock solution was combined with 1 $\mathrm{mL}$ of tannic acid solution and precipitation reactions were allowed to proceed under refrigeration for $18 \mathrm{hr}$ after which samples were centrifuged $(3,000 \mathrm{~g}$ for $10 \mathrm{~min})$ and the precipitate was dissolved in SDS solution $(1 \% \mathrm{w} / \mathrm{v})$. The aliquot of $1 \mathrm{~mL}$ of resulted solution was combined with 3 mL TEA- SDS solution (7\%TEA \& 1\% SDS). After several minutes 1 $\mathrm{mL}$ of $\mathrm{FeCl}_{3}$ was added and the optical density was measured after $60 \mathrm{~min}$ incubation at room temperature, then absorbance was measured at 520 $\mathrm{nm}$, zeroing the spectrophotometer with a tube containing all of the reagents plus water in place of the extract. Tannin contents were determined according to calibration curve $\left(\mathrm{R}^{2}=0.971\right)$ which was constructed from commercial tannic acid ranging from $10-50 \mathrm{~g} / \mathrm{L}$.

\subsubsection{Molecular Identification}

Bacterial DNA was extracted from the samples, the final DNA concentration determined and DNA quality was checked by $1 \%$ AGE after purification. The PCR product was then sequenced using the primers and the unincorporated PCR primers and dNTPs from PCR products were removed. Single-pass sequencing was then performed on each template using below 16s rRNA universal primers and the fluorescent-labeled fragments were purified from the unincorporated terminators. The samples were resuspended in distilled water and subjected to electrophoresis. RNA sequence analysis was employed to characterize and identify bacterial species. The $16 \mathrm{~S}$ ribosomal RNA sequences obtained were analyzed by using the BioEdit software and then aligned by ClustalW. The 16S rDNA sequence was compared with the sequences in GenBank by using standard BLASTn search to check for similarities with the already found strains of the bacteria Bacillus subtilis.

\section{Results and Discussion}

\subsection{Identification and Characterization of the Isolated Bacteria}

The research study was initiated to isolate, cultivate and identify tannic acid degrading bacteria from the decaying portion of barks. Decaying barks were chosen as a probable source for the isolation of tannin degrading bacteria as it had high probability of having bacterial degraders that would have breached the guard of the tree's first defence against microbes, tannins. It was thought that decaying portions of the bark will be the apt source to isolate tannin-degrading bacteria, where tannins are no longer able to inactivate the invasive extracellular enzymes of microbes and where microbes that can invade the protective layer of tannins could possibly be present.

Bark samples were inoculated on minimum salts medium to isolate tannic acid degrading microorganisms. Since tannic acid can form complexes with proteins and other compounds, it is difficult to use organic sources of carbon, nitrogen and proteins in the growth medium [29]. Therefore, isolation of tannase producers required a specific media, such as, MSM with tannic acid as the source of carbon [30]. Their presence was confirmed by growing them in increasing concentration of tannic acid (0.1-0.5\%). Three isolates (I-1, I-2, I-3) showed growth on medium containing $0.1-0.5 \%$ tannic acid. These three isolates were further cultivated for colony, physiological and biochemical characterization as shown in Table 1 and 2.

Table 1 Morphological characteristics of the three isolates

\begin{tabular}{llllll}
\hline & Gram stain & Morphology & Colony shape & Colony size & Margin \\
\hline Isolate 1 & Positive & Rod shaped & Irregular white & $<1 \mathrm{~mm}$ & Entire \\
Isolate 2 & Positive & Rod shaped & Circular white & $<1 \mathrm{~mm}$ & Entire \\
Isolate 3 & Positive & Cocci & White rhizoid & $>1 \mathrm{~mm}$ & Filiform \\
\hline
\end{tabular}

Table 2 Biochemical characteristics of the three isolates

\begin{tabular}{llll}
\hline Biochemical Test & Isolate 1 & Isolate 2 & Isolate 3 \\
\hline Methyl Red & Positive & Positive & Positive \\
Voges Proskauer & Negative & Negative & Negative \\
Indole Production & Negative & Negative & Negative \\
\hline
\end{tabular}

These results of the biochemical tests that were performed, indicate that all the isolates could ferment glucose but could not produce the enzyme tryptophanase or butane-2,3-diol. 


\subsection{Tannase Activity}

\subsubsection{Maximum Tolerable Concentration}

The isolate I-1 showed a maximum tolerable concentration of tannins of $50 \mathrm{~g} / \mathrm{L}$ among the three isolated bacteria and was thus chosen as the most efficient tannin degrading bacteria for further tests.

\subsubsection{Visual Detection Assay}

Tannin-protein complex (T-PC) degrading activity of the isolate-1 was checked on plate containing nutrient agar coated with tannic acid, forming T-PC, which shows an opaque shiny color of the medium. A zone of clearance formed by reduction of opacity around the colonies of I-1 was taken as indication of the hydrolysis of T-PC. Acidic $\mathrm{pH}$ around the colonies, tested by touching $\mathrm{pH}$ indicator strip near the colonies was indicative of the release of tannic acid. The clearing zone turned brown after $24 \mathrm{hr}$, presumably because of the oxidation of tannic acid released after the hydrolysis of T-PC as seen in Fig. 1 [31].

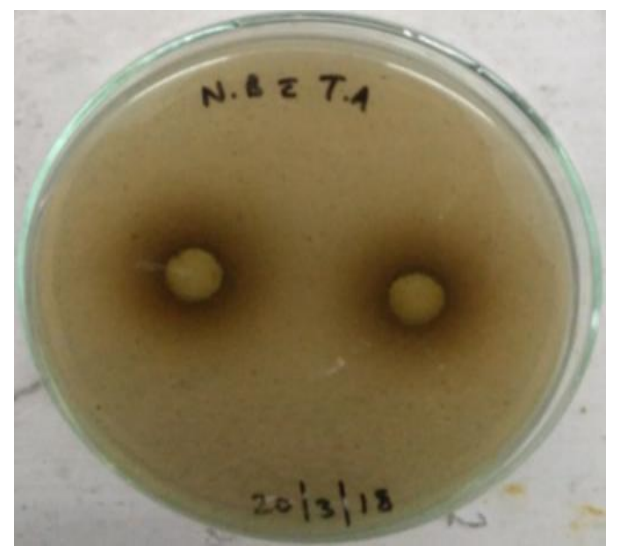

Fig. 1 Tannase activity test

\subsubsection{BSA Precipitation Assay}

Tannin concentrations were also measured by bovine serum albumin (BSA) precipitation assay and the biodegradation percentage was calculated. One of the potential mechanisms of polyphenols action on bacterial cells is that polyphenols can bind to bacterial cell membranes in a dose- dependent mode [32]. In biodegradation experiment, tannic acid utilization as the sole carbon and energy source resulted in visual turbidity increase with a simultaneous production of acidic metabolites as indicated by an additional decrease in the $\mathrm{pH}$ of the medium [24]. The primary $\mathrm{pH}$ of culture fluid was 5.9 that decreased to 3.39 - 4.15 after $96 \mathrm{hrs}$ of incubation. A gradual decrease in the concentrations of tannic acid was observed with the increasing incubation period, noted up to 144 hours as seen in Fig. 2. Tannic acid degradation was at its peak after $72 \mathrm{hrs}$ of incubation. Also, the degradation percentage of tannic acid at concentrations of $10 \mathrm{~g} / \mathrm{L}, 20 \mathrm{~g} / \mathrm{L}$, and $30 \mathrm{~g} / \mathrm{L}$ reached more than $90 \%$ after $144 \mathrm{hrs}$ incubation, while for concentrations of $40 \mathrm{~g} / \mathrm{L}$ and $50 \mathrm{~g} / \mathrm{L}$, the degradation percentage reached a maximum of up to $60 \%$.

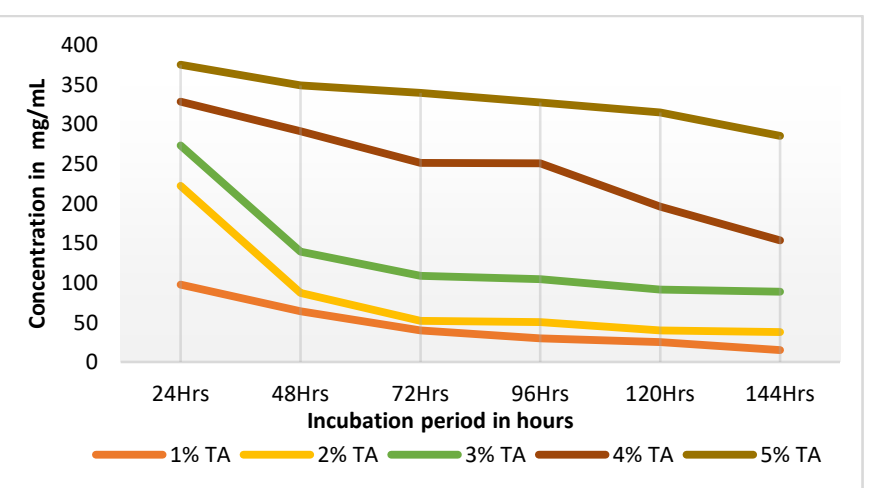

Fig. 2 Graph indicating tannic acid degradation with increasing time

\subsubsection{Tannase Specific Assay}

Tannase specific assay was also done using the Miller's method where tannase breaks tannic acid which acts as a substrate, forming Gallic acid and liberating glucose. Tannase activity was determined by estimating the reduced glucose liberated using 3,5-dinitrosalicylic acid reagent. From the results below (as shown in Fig. 3) it was clear that the enzyme activity of isolate giving $51.61 \mathrm{U} / \mathrm{mL}$ was the optimum after 96 hours of incubation https://doi.org/10.30799/jnpr.100.21070201 for enzyme production. The graph below represents the enzyme activity of the isolate at different hours. The method determines the amount of glucose liberated in the production medium and so it gives such high values for enzyme activity.

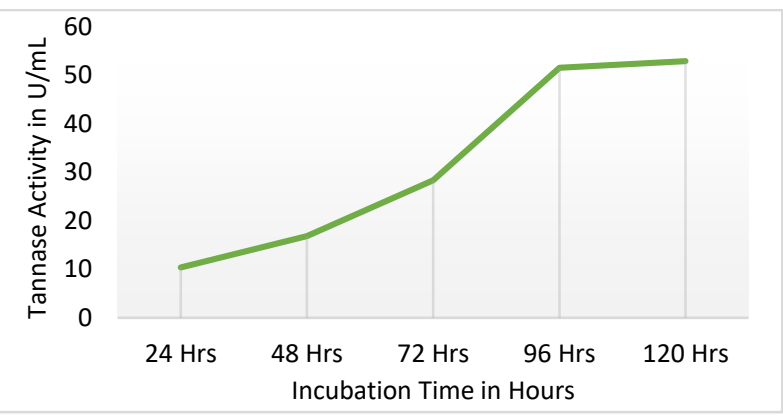

Fig. 3 Tannase activity of the Bacillus subtilis strain

\subsubsection{Molecular Identification}

The isolated bacterial strain was subjected to $16 \mathrm{~S}$ rRNA sequencing and was compared with the available $16 \mathrm{~S}$ ribosomal sequences in the NCBI database using BLASTn. The tannin degrading bacteria has been enrolled into a cluster containing Bacillus sp. and was found to have $96 \%$ identity with Bacillus subtilis as shown in the Fig. 4. While the multiple sequence alignment and phylogenetic tree construction reveals that the Bacillus subtilis strain used in this study is closely related to Bacillus methylotrophicus strain MER 163 as well as to Bacillus subtilis strain 10A but is not one among the already found strains. The newly identified strain of Bacillus subtilis, namely I-1, was then submitted to NCBI under the accession number MH330408.

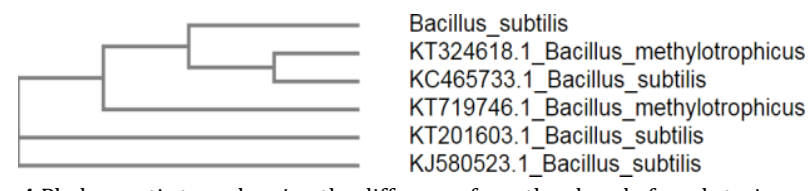

Fig. 4 Phylogenetic tree showing the difference from the already found strains

\section{Conclusion}

In the degradation mechanism of tannin, microbes play an important role by secreting the enzyme tannin acyl hydrolase or tannase, which is capable of catalyzing gallotannins to gallic acid and glucose. And although gallic acid is widely distributed in nature, it is difficult for bacteria to use it as a carbon source for growth at neutral or alkaline $\mathrm{pH}$, unlike glucose. In this study, tannic acid degrading Bacillus $s p$ was isolated from decaying tree bark. Bacterial strains degrading tannic acid have been previously isolated from different sources such as oil mill wastes, goat, cow or mouse feces pistachio soft hulls and soil. Our findings along with the fact this strain is able to grow on higher concentrations of tannic acid (that is up to $50 \mathrm{~g} / \mathrm{L}$ ) give them an amazing potential for its application in bioremediation, waste water treatment, and also reduction of antinutritional effects of tannins in animal feeds. It could also be very valuable in industry for production of tannase. Furthermore, the ability of the isolate (Bacillus subtilis strain I1) characterized in this study provides novel insights for the role it can play in composting of tannin containing wastes. The research on biodegradation of tannins is in an incipient stage and further studies must be carried out. Such studies apart from helping us to understand the phenomenon of nature, ecology of microbial succession and allelopathic effects, will also aid to exploit the potential of various tannase for large scale production and its applications in food, fodder, and medicine and tannery effluent treatment. This bacterial isolate may have use in clarification of fruit juices, residues of coffee pulp, thus being a good alternative to solve the big problem that represents the accumulations of this agro industrial byproduct in some developing countries like Brazil, Mexico, or Colombia. Furthermore, these tannase producing bacteria may find application in food (clarification of fruit juices), pharmaceutical industries and can be used in the study of genes involved in the production of tannase, an industrially important enzyme.

\section{Acknowledgement}

We sincerely thank Mr. Selvakumar and Ms. Dhivya from BioLim Centre for Science and Technology; and Prof. Anitha Dorothy Sebastian, Loyola College, for their guidance and support towards this paper. 


\section{References}

[1] S.P. Chowdhury, S. Khanna, S.C. Verma, A.K. Tripathi, Molecular diversity of tannic acid degrading bacteria isolated from tannery soil, J. Appl. Microbiol. 97 (2004) 1210-1219.

[2] G.W. Sanderson, N.J. Englewood, P. Coggon, N.Y. Orange- burg, Green tea conversion using tannase and natural tea leaves, U.S. Patent, 3, 812 (1974) 266.

[3] T.K. Bhat, B. Singh, O.P. Sharma, Microbial degradation of tannins-A current perspective, Biodegradation 25 (1998) 343-357.

[4] S.S. Deshpande, S.K. Sathe, D.K. Salunkhe, Chemistry and safety of plant phenols, Adv. Exp. Med. Biol. 177 (1984) 457-495.

[5] E. Haslam, Plant polyphenols-vegetable tannins revisited, Cambridge University Press, Cambridge, 1989.

[6] C.N. Aguilar, G. Gutierrez-Sanchez, Review sources, properties, applications and potential uses of tannin acyl hydrolase, Food Sci. Technol. Int. 7 (2001) 373-382.

[7] J. Lima, R. Cruz, J. Fonseca, Production, characterization of tannase from Penicillium montanense URM 6286 under SSF using agroindustrial wastes, and application in the clarification of grape juice (Vitis vinifera L.), Sci. World J. 2014 (2014) 182025.

[8] J. Field, G. Lettinga, Biodegradation of tannins, Metal ions in biological systems, Volume 28, In: H. Sigel (Ed.), Degradation of environmental pollutants by microorganisms and their metalloenzymes, Marcel Dekker, New York, 1992, pp.61-97.

[9] D.P. Belur, G. Mugeraya, K.R. Nirmala, N. Basavaraj, Production of novel cellassociated tannase from newly isolated Serratia ficaria DTC, J. Microbiol. Biotech. 20 (2010) 732-726.

[10] V.L. Singleton, F.H. Kratzer, Toxicity and related physiological activity of phenolic substances of plant origin, J. Agric. Food. Chem. 17 (1969) 497-512.

[11] R.D. Haworth, K. Jones, H.J. Rogers, Ion-exchange chromatography of Aspergillus niger extract, Proc. Chem. Soc. 8 (1985) 8-9.

[12] K. Chung, T.Y. Wong, C. Wei, Y. Huang, Y. Lin, Tannins and human health: A review, Crit. Rev. Food Sci. Nutr. 38(6) (2016) 421-464.

[13] S. Garg, H. Makkar, K. Nagal, S. Sharma, D. Wadhwa, B. Singh, Toxicological investigations into oak (Quercus incana) leaf poisoning in cattle, Vet. Hum. Toxicol. 34 (1992) 161-164.

[14] A.Z. Mazni, Y.W. Ho, I. Azizul, A. Nurdin, Antioxidant, antimicrobial and cytotoxic potential of condensed tannins from Leucaena leucophala hybridRendang, Food Sci. Hum. Wellness 5 (2016) 65-75.

[15] Y.H. Wu, M. Meng, Y.C. Zhao, J.H. Liu, G.Q. Fang, S. Zhang, Study on the key technology of Chaenomeles speciose juice, Food Ferm. Indus. 40(1) (2014) 222225
[16] P.K. Lekha, B.K. Lonsane, Production and application of tannin acyl hydrolase: state of the art, Adv. Appl. Microbiol. 44 (1997) 215-260.

[17] J.A. Lewis, R.L. Starkey, Decomposition of plant tannins by some soil microorganisms, Soil Sci. 107 (1969) 235-241.

[18] A.M. Deschamps, Microbial degradation of tannins and related compounds, in: N.G. Lewis and M.G. Paice (Eds.), Plant Cell wall polymers biogenesis and biodegradation, American Chemical Society, Washington, DC, 1989, pp.559566.

[19] R.O. Osawa, K. Kuroiso, S. Goto, Isolation of tannin degrading Lactobacilli from humans and fermented foods, Microbiol, A.P.P.L.E.N.M. 66(7) (2000) 30933097.

[20] G.S. Cherian, Biodegradation of tannery effluents for sustainable leather production, in: E.N. Oparah (Ed.), Sustainability of leather sector in developing countries, Delhi, India, 2020, pp.75-99.

[21] Y. Nishitani, R. Osawa, A novel colorimetric method to quantify tannase activity of viable bacteria, J. Microbiol. Methods 54(2) (2003) 281-284.

[22] A. Sher, Antimicrobial activity of natural products from medicinal plants Gomal J. Med. Sci. 7(1) (2009) 72-78.

[23] P. Sachan, S. Madan, A. Hussain, Isolation and screening of phenol-degrading bacteria from pulp and paper mill effluent, Appl. Water Sci. 9(4) (2019) 1-4.

[24] A. Tahmourespour, N. Tabatabaee, H. Khalkhali, I. Amini, Tannic acid degradation by Klebsiella strains isolated from goat feces, Iran. J. Microbiol. 8(1) (2016) 14-20.

[25] R. Osawa, T.P Walsh, Visual reading method for detection of bacterial tannase, Appl. Environ. Microbiol. 18 (1993) 74-78.

[26] D. Brahmbhatt, H.A. Modi, Comparative studies on methods of tannase, Int. J. Res.Appl. Sci. Eng. Technol. 3(3) (2015) 715-720.

27] A. Tahmourespour, N. Tabatabaei, H. Khalkhali, I. Amini, Study of tannindegrading bacteria isolated from Pistachio soft hulls and feces of goat feeding on it, Biol. J. Microorg. 5(20) (2017) 61-69.

[28] B.A. Biochem, Y. Hussein, I. Mohammed, Isolation and characterization of tannic acid hydrolysing bacteria from soil, Biochem. Anal. Biochem. 5(1) (2016) 1-6.

[29] B. Prassana, R. Goud, D. Goudar, Optimization of culture medium for novel cellassociated tannase production from Bacillus massiliensis using response surface methodology, J. Microbiol. Biotech. 22(2) (2012) 199-206.

[30] S. Sarang, D. Vora, Isolation of tannase producers from soil, Int. J. Res. Biosci. 4(3) (2015) 49-55.

[31] Y.H.I. Mohammed, Isolation and characterization of tannic acid hydrolysing bacteria from soil, Biochem. Anal. Biochem. 5 (2016) 254-259.

[32] F. Cardona, C. Andrés-Lacueva, S. Tulipani, F.J. Tinahones, M.I. QueipoOrtuño, Benefits of polyphenols on gut microbiota and implications in human health, J. Nutr. Biochem. 24 (2013) 1415-1422. 